\title{
REVISTA CIDOB d'AFERS INTERNACIONALS 82-83.
}

\section{Boundaries: Transience and}

intercultural dynamics.

The Cosmopolitan Imagination. Gerard Delanty 


\title{
The Cosmopolitan Imagination \\ Gerard Delanty*
}

\begin{abstract}
This article deals with the importance of cosmopolitanism as a world force in relation to Europeisation and to the wider context of globalization. The author examines the implications for Europe of the process of global social transformation, and in what way a cosmopolitan political project is required. Cosmopolitanism can be considered as an alternative to both, nationalism and globalisation, but for this purpose it should be a critical cosmopolitanism, a cosmopolitanism that is capable of asking questions and empirically testing the hypotheses of cosmopolitanism. Cosmopolitanism today unlike in the past is post-universal and entails the recognition of the existence of a multiplicity of cosmopolitan projects in the world. It is not an exclusively Western project, but can exist anywhere and at anytime. A general working definition of cosmopolitanism should be articulated as an attempt by social sciences aimed at identifying processes of self-transformation that arise from encounters with Others, in the context of global concerns.
\end{abstract}

Key words: Cosmopolitanism, cultural diversity, cultural pluralism, globalisation, social restructuring, transnationalism, universalism

Cosmopolitanism has been for long associated with western moral and political philosophy. The major philosophical proponents of cosmopolitanism, which in modern times derives from Kant, have tended to associate cosmopolitanism with a universalistic orientation towards world community (Bohman and Lutz-Bachmann, 1997). In Greek philosophy, for the Stoics and Cynics cosmopolitanism signified an allegiance to the world community as opposed to the community into which one was born. For 
Kant it was primarily a demand for the recognition of universal rights. While much of cosmopolitan philosophy operates on a highly normative level, as is best exemplified in the work of political theorists such as David Held, it has had a considerable impact in social sciences and history. Cosmopolitanism, too, has been reflected in developments in global history, cross-cultural encounters in history and in studies of alternatives modernities (Gaonkar, 2001). The attraction of cosmopolitanism for social scientists consists in part of its normative orientation, which is especially relevant to transnationalism and the growing consciousness of globality. Rather than being a utopian projection or, as in Nussbaum's (1996) well known essay, a moral postulate, it has a resonance in a wide range of cultural, social and political currents throughout the world.

Cosmopolitanism has emerged as an important theoretical approach in the social sciences in recent years. Originally a development within moral and political philosophy concerning an universalistic orientation towards world principles it has become increasingly pertinent to social science especially in the context of issues relating to globalization and transnational movements of all kinds. It would not be inaccurate to speak of a cosmopolitan turn in social science ${ }^{1}$. Cosmopolitanism suggests a critical attitude as opposed to an exclusively interpretative or descriptive approach to the social world. In this sense it retains the normative stance of traditional notions of cosmopolitanism.

One of the principal expressions of cosmopolitanism as a political condition concerns the search for alternatives to purely instrumental economic and security relations between societies. While cosmopolitanism has become influential within normative political theory, it has been taken up in a different guise in disciplines such as history, sociology, anthropology, cultural studies where the tendency has been towards a more situated or rooted understanding of cosmopolitanism. Rather than a preoccupation with exclusively universalistic principles, the cosmopolitan turn in the social sciences has tended towards a post-universalistic stance ${ }^{2}$. This has led to a view of globality as seen through the lens of the local. The resulting relativization of universalism opens cosmopolitanism to more empirically relevant applications.

Of particular relevance is the recognition of a multiplicity of cosmopolitan projects in the world. It is not an exclusively western project but can exist anywhere and at anytime. Cosmopolitan cultural and political orientations can be expressed in individuals, in collective actors such as organizations and social movements, in populations such as diasporas, and even in whole societies or civilizational currents. However, cosmopolitanism is not simply reducible to transnationalism, although transnationalism is an important precondition of cosmopolitan orientations. To speak of cosmopolitanism is to refer to a transformation in self-understanding as a result of the engagement with others over issues of global significance. It is concerned with identifying processes of self-transformation arising out of the encounter with others in the context of global concerns. 


\section{CRITICAL COSMOPOLITANISM}

The distinctive feature of the cosmopolitan approach I am proposing here can be called critical cosmopolitanism (see Delanty, 2006a). This is distinguished by its aim to be empirically relevant but also evaluative. In normative terms it is significant with respect to the current situation; it is also crucial in terms of cosmopolitanism itself, that is in interrogating and testing the hypotheses of cosmopolitanism in empirical ways.

Much of cosmopolitan theory in social science tends to be either exclusively normative, as is the case with cosmopolitan political theory, or -as is the case in most social and historical work- concerned with an all too diffuse notion of transnational movements or cultural hybridity. In the former case there is little engagement with actual empirical examples and, in the latter case, the link with the normative is often lost in a preoccupation with issues of diversity, mobility, hybridity etc and there is often an unclear connection with globalization. Any serious application of cosmopolitanism to social analysis requires moving beyond purely normative considerations to assessing concrete developments. But how do we do this without losing the normative dimension of cosmopolitan analysis?

Cosmopolitanism is a post-universalistic condition that is open to a diversity of interpretations and applications. Identifying cosmopolitanism with self-transformation in light of the encounter with others in responses to the challenges of globality, it is possible further to specify it as a condition that occurs through deliberation. It is through deliberation, as Habermas has argued, that hitherto assumptions are revised in light of the perspective of the other. In this sense cosmopolitanism is dialogic but also critical. In another sense, critical cosmopolitanism offers a normative standpoint to assess the current situation, for instance to assess the preconditions of cosmopolitanism in a particular context or to assess the extent to which a given situation is one in which cosmopolitanism is a significant factor.

The critical cosmopolitanism advocated here avoids the pitfalls of universalism (purely normative advocacy) and relativism (whereby cosmopolitanism is equated by hybidity and pluralism). Some of the characteristics that are generally associated with cosmopolitanism such as the negotiation and crossing of borders, a concern with overlapping allegiances, a concern with global equality and the suffering of others, are thus given a more concrete form in specific methodological approach the aim of which is to discern and assess empirical expressions of cosmopolitanism. As post-universalistic selfunderstanding, cosmopolitanism can be seen more as a self-problematization and as a learning from the other. In that sense it is a universalism modified by relativism; it is not European universalism, but exists in a variety of contexts and to varying degrees. For instance, it is possible to see cosmopolitanism expressed in the mixing and re-packaging 
of cultures and identities. This might be a weak expression of cosmopolitanism but, depending on the degree of self-transformation that results, it may also take a stronger form. Recognition of the perspective of the other is the key to cosmopolitanism and it makes little sense speaking of cosmopolitanism if this is absent. In situations of a largely transnational nature where self-problematization and pluralization result from the encounter with others we can speak of cosmopolitanism. Cosmopolitanism in this sense, then, is related to the capacity for self-transformation in the cultural and political resources of a society or a given social form.

A critical cosmopolitan approach offers an alternative to internationalism as well as to globalization oriented approaches. Where the former is largely a matter of inter-state relations and the latter a process in which time and space become compressed, cosmopolitanism is rather a response to the normative implications of the international order and to globalization and comes into play whereever alternatives to exclusively economic and security concerns are explored. So, for example, cosmopolitanism as opposed to globalization can be expressed in movements aimed at bringing global forces under the control of cosmopolitan publics and cosmopolitan states. One of the characteristic features of cosmopolitanism as opposed to internationalism or globalization is the link with the local. Cosmopolitan politics take place in the nexus of the local and the global in much the same way as it is a condition that goes beyond the universal versus relativist poles. Cosmopolitanism can be seen as constituting a field of tensions that arises whenever the local and the global come into contact. In addition, critical cosmopolitanism is distinguished from superficial or pseudo "cosmopolitanism" which focuses only on the use of the life style of other cultures to enrich one's material life without normative engagement.

\section{COSMOPOLITANISM AND THE NATION}

This does not mean that the category of the nation is no longer relevant to political community. Globalization does not present an alternative to the idea of a national community for several reasons. Globalization has brought about not so much the end of national forms of political community than their transformation. One of the most important expressions of this transformation of national identities is cosmopolitanism. The crucial point is that much of cosmopolitan transformation has emanated from the transformation within national identity under the conditions of globalization.

To reiterate a point made earlier, cosmopolitanism arises out of local and global links; it is not simply the rule of the global over the local. Cosmopolitan refers to the end of the "closed society" of the nation-state, but it does not spell the end of the nation. 
Various cosmopolitan theorists thus speak of a "rooted cosmopolitanism" to refer to what is a really existing cosmopolitanism in the world today and which corresponds to multiple attachments and forms of belonging (see Appiah 2005). The nation-state is itself is a demonstration of the cosmopolitan principle that people can imagine a political community beyond the context of their immediate world. So it is possible to see contemporary cosmopolitanism as an extension of the cosmopolitanism of the national community to an acknowledgement of a wider political community beyond the national community.

\section{COSMOPOLITANISM AND TRANSNATIONALISM}

Cosmopolitanism is often equated with diversity and hybridity. This is particularly the case with cultural conceptions of cosmopolitanism, which is often related to global culture, diasporas, and various kinds of transnationalism movements in which identities and culture become mixed. For Urry (2002), who also aligns his position with cosmopolitanism, the key feature of the current situation is the fact of mobility. Urry argues mobility is expressed in processes as different as global complexity and reflexive modernity: people, commodities, cultures, technologies are all mobile and their reality is one of mobility. Mobilities are not just flows but networked relations and are globally organized in new kinds of spaces and temporal processes. In opposition to this emphasis on mobility and hybridity as the chief characteristics of cosmopolitanism, I am arguing that cosmopolitanism cannot be entirely separated from the normative vision of alternative society and that this imaginary is also present as a cultural model within the cultural traditions of societies.

Cosmopolitanism is not a straightforward product of globalization but arises out of the encounter of the global with the local or national. In this sense, then, it exists in relations of tension and in transformative dynamics; it is not a given condition or goal to be reached. In other words cosmopolitanism exists within all societies and can be seen as a transformative process (see Beck, 2005).

Critical cosmopolitanism is not merely about plurality. Although this is one key aspect of cosmopolitanism, it is not the main or only aspect: cosmopolitanism is not a generalized version of multiculturalism where plurality is simply the goal. A post-universalistic conception of cosmopolitanism should rather be seen in terms of the tensions within modernity. Of particular importance in this respect is the tension between the global and the local, on the one side, and on the other the universal and the particular. It is possible to see this tension which is expressed through communication as constituting the basic animus of cosmopolitanism. While diversity is one outcome, it is not 
the only one and not any more so than is a universal global order. So against notions of globalization and universality, on the one side, and plurality and particularism on the other, the cultural dimension of cosmopolitanism consists more in the creation and articulation of communicative models of world openness in which societies undergo transformation. The inevitable diversity that comes from the pluralization of cultural traditions should not detract from processes of communicative transformation that arise as a result of responses to the presence of global publics. Cosmopolitan culture is one of self-problematization and while diversity will, by the pluralizing nature of cosmopolitanism, be inevitable the reflexive and critical self-understanding of cosmopolitanism cannot be neglected. Cosmopolitanism must be seen as one of the major expressions of the tendency in modernity towards self-problematization. Cosmopolitanism concerns processes of self-transformation in which new cultural forms take shape and where new spaces of discourse open up leading to a transformation in the social world. The cosmopolitan imagination from the perspective of a critical social theory of modernity tries to capture the transformative moment, interactive relations between societies and modernities, the developmental and dialogic aspect. For these reasons methodologically speaking a critical cosmopolitan sociology proceeds on the assumption that culture contains capacities for learning and that societies have developmental possibilities.

\section{SOME METHODOLOGICAL CONSIDERATIONS}

It is useful to distinguish four levels of cosmopolitan analysis: preconditions, cultural orientations, political consequences, and societal transformations. The aim of this differentiated approach is to distinguish cultural and political expressions of cosmopolitanism and to overcome the divergence of empirically and normatively oriented approaches:

1. Preconditions. Rather than identify consopolitanism with a fully developed condition, it can be helpful to identify preconditions of cosmopolitanism. This involves, for instance, addressing the cultural logic by which societies undergo change as a result of interaction with other societies. Relevant considerations are civilizational elements, intellectual traditions that have been carriers of cosmopolitan ideas, social actors and even instructions.

2. Cultural orientations. Some societies and collective actors have stronger predispositions towards cosmopolitanism than others. Identifying cultural orientations operative in various contexts can be a useful way to analysis the emergence of cosmopolitanism. 
3. Political consequences. It is important to link cosmopolitanism with politics and changes in collective self-understandings. Relevant in this context is, for example, processes of norm building and policy shifts.

4. Societal transformation. There is a level of analysis that relates to the wider societal context and which is not identifiable by reference simply to specific instances. Cosmopolitanism can also be viewed as a condition that concerns the formation of an emergent reality and is identified by reference to developmental, interactive, and transformative processes. A major shift in the moral and cultural outlook of a society would be an example of this.

\section{COSMOPOLITANISM AND EUROPE}

Europeanization offers an interesting illustration of cosmopolitan developments. By the term Europeanization is not meant simply "European integration" or the Europeanization of the nation-state as a result of the EU, but a wider process of the Europeanization of European societies (See Delanty and Runford, 2005). The role of the $\mathrm{EU}$ in this cannot be underestimated and is without doubt the single most important factor in enhancing the capacities of European societies to become cosmopolitan. However, as a transnational project it is not to be equated with cosmopolitanism. It is helpful to begin by identifying some of the preconditions of cosmopolitanism in Europe before specifying some of its more overt expressions.

The basic preconditions of cosmopolitanism within Europe have been established by the Europeanization of the nation state as a result of the consolidation of the European Union over the past two decades during which time the project of European integration came to be increasingly addressed to wider societal issues. The EU can be seen as a catalyst of cosmopolitanism without itself being necessarily cosmopolitan. The sharing of sovereignty and the undermining of national autonomy has opened up opportunities for cosmopolitanism to become more rooted in European societies than in previous times when national societies were relatively autonomous. With the transformation of the European project into one of normative transnationalism as opposed to a purely inter-governmental organization, the external preconditions for European cosmopolitanism were established. It is important not to conflate such preconditions with a fully developed cosmopolitan condition, since the EU itself is not cosmopolitan by virtue of being a transnational actor. Although a case could be made to see the EU as itself an instance of cosmopolitanism, the position taken here is to see it as a catalyst of cosmopolitan change. It must be borne in mind that the EU can also lead to counter- 
cosmopolitanism, as in Milward's (1993) well known thesis of the "European rescue of the nation-state" or the argument, which has some plausibility, that the EU provokes nationalism (Hutchinson, 2005).

Europeanization has not led to a European Society and it is also the case that a European political community has failed to rival the obvious popularity of national identity; yet, there can be little doubt that the tremendous transformation of the nation state as a result of Europeanization has opened the ground for cosmopolitan orientations. There is now ample empirical evidence of the interpenetration of European societies to a degree that has never before been the case. This is particularly evident in the dilution of borders within the EU and the more or less total disappearance of war within the EU. It is for instance inconceivable that Germany and France will once again go to war. Europe too has been the context in which countries such as Ireland have been able to overcome the legacy of history and in the case of Ireland have found a more balanced relationship with their neighbour. A pertinent example of cosmopolitan politics in this context is the creation of power-sharing whereby the UK and Irish governments have joint sovereignty over Northern Ireland. At this point we can speak of an overt expression of cosmopolitanism, that is a transformation in the cultural and political orientation of society as a result of the encounter with others. The transnational space that has been opened by Europeanization has provided such possibilities the results of which are, as already argued, best exemplified in the national or local space rather than in the transnational space as such. This, again, is an example of how cosmopolitanism should be seen as a transformative condition in which the local responds to the challenges of the global. So the thesis advanced here is that the Europeanization of national societies has established preconditions for cosmopolitanism to emerge and whether or not this happens is an empirical question. For example, the enlargement of the EU to include much of central and eastern Europe can be seem as setting a precondition of cosmopolitanism in that it has led to the emergence of a multi-centred Europe, which can no longer be defined in terms of a narrow western conception of Europe and the European heritage. But whether or not this tendential "post-western Europe" in the making will actually develop in a cosmopolitan direction is an open question (Delanty, 2003). The current debate about the draft Constitutional Treaty and the question of Turkish membership is an example of a discourse in which cosmopolitan and counter-cosmopolitan currents can be found.

The current situation suggests that Europeanization has reached a decisive juncture: either it remains an intergovemental organization with limited social and cultural aims or becomes a polity based on a political community. To achieve the latter, which appears to be the goal, a deepening of the democratic heritage is needed. To an extent this has already occurred even if it is not manifest on the level of overt legitimacy as measured by voting behaviour and public opinion. Europeanization resembles more closely the 
model of cosmopolitanism: a multilevel, unilinear process by which nation-states and societal systems are themselves transformed by a movement that is not entirely to be explained by an EU master-plan.

Cosmopolitan tendencies are evident in changing identity patterns. There is now adequate empirical evidence of European identity as an identity that is not necessarily in competition with national or regional or ethnic identities, but an identity than can co-exist with other kinds of identity and with which it may have a reflexive relation (Herrmann et al 2004). This dimension of reflexivity is an important indicator of cosmopolitanism in so far as it suggests a problematization of self-understandings. An interesting example of this is the Europeanization of Turkish Islam, that is the tendency by which Islam in Turkey has become an agent of democratization as a result of its willingness to undergo change. Further examples of at least partial cosmopolitanism are the growing Europeanization of public discourse. Although a European public sphere does not exist as such, the interpenetration of European public spheres has resulted in a more and more forms of interaction between European societies and emerging out this are instances of cosmopolitan consciousness. A pertinent example was European wide civil opposition to the Anglo-American led war in Iraqi.

This is clearly a limited outline of the case for the relevance of cosmopolitanism to developments related to Europeanization. However, it does seem incontrovertible that if cosmopolitan theory is to have any empirical application the emergence of European normative transnationalism is one of the most obvious candidates in the world. There are few transnational fields where the dilution of national sovereignty has been so extensive and where normative orientation beyond economic and security issues play a significant role. While this transnational normative order can be identified with the EU, it should be related to the much wider scenario of a post-national Europe that has been transformed by cross-national interactions and the move towards a post-sovereign polity.

\section{COSMOPOLITANISM BEYOND EUROPE}

Cosmopolitanism is not a European or universal western condition but occurs in a variety of societal forms. There are European and Asian expressions of cosmopolitanism, a term that can be taken to be a concern with global principles of justice and the need to take into account the perspective of the other. Until now the dominant conceptions of cosmopolitan have focused on universal justice, identifying cosmopolitanism with a universal normative order. One of the principal correctives of this has been a concern with European versions of cosmopolitanism (Habermas, 2003; Beck and Grande, 2007). 
In such approaches European integration as a postnational process is seen as entailing cosmopolitan cultural and political possibilities. But we need to go beyond a limited European perspective and bring the Asian experience to bear on the debate on the multiple expressions of cosmopolitanism. Such a perspective offers a richer and more culturally nuanced analysis of the huge variety of normative frameworks that exist in the world and, moreover, offers a basis for a new conception of transcontinental dialogue.

It is increasingly recognised that Asia is important for Europe. Unprecedented social change in Asia - economic, demographic, political, and cultural - has compelled a new approach. The centre of global power is slowly shifting from West to East and already global markets are making a huge impact on Europe (Frank, 1998; Therborn, 2006). Europe can either embrace global markets - and face nationalist reaction in Europe - or it can resist globalization by retreating into a Fortress Europe. If Europe resists globalization by economic protectionism and increased security etc anti-western sentiments will be provoked in Asia. Neither of these options can be a basis for the future. Due to economic interdependency and with its growing consciousness as a global actor, Europe will have to find more positive ways of relating to Asia. Together Europe and Asia need to solve together the problems of the world risk society.

Asia is important for Europe, both for individual nation-states and the EU. The EU itself has been developing an interest in the external and global context in which Europe is increasingly becoming an actor in the world (Lavenex, 2004). Europe, too, is important for Asia, where there is increased interest in developing relations that are not exclusively based on national interests. Although the obstacles to cosmopolitanism cannot be underestimated, there is much to suggest that in fact Europe and Asia have the necessary social and political resources to draw from in order to move beyond national interests and at the same to resist the normless world of globalization.

It has been increasingly accepted that within Europe national interests alone cannot be self-determining. The project of European integration, which led to a dilution of national sovereignty, arose out of this recognition, but in the wider international context national interests on the whole are predominant and often such interests are rooted in cultural and even in civilizational worlds. The EU is an exception in so far as it is a polity based on overlapping layers of governance in which the national level is only one tier and indeed one that has been considerably modified by a transnationalization of the nation-state. Recent studies have demonstrated the relevance of cosmopolitanism for Europeanization (Delanty and Rumdford, 2005; Rumford, 2006; Beck and Grande, 2007). There are not many other comparable models of governance in the world. Nowhere is this more evident than in the case of the United States, despite its democratic political culture. However, there is some evidence to suggest that in the case of Euro-Asian relationships there is a shift towards what might be called a cosmopolitan perspective whereby national interests are modified by transnational cooperation. Transnational citizenship and global civil society has become 
increasingly operative in the Asian context (He, 2004a). On the level of culture, contrary to popular slogans such as the "clash of civilizations", there is also some evidence of cosmopolitan possibilities for dialogue.

\section{CONCLUSION}

Critical cosmopolitanism can be an alternative to nationalism and to a narrowly defined globalization. A major question is whether positive political forms of cooperation will develop along cosmopolitan lines, that is will go beyond narrow economic and security concerns to address problems of global justice. This question is also a cultural question and concerns the capacities of a given society to transform itself in light of the perspective of the other.

A major challenge today is the development of dialogue across cultural and civilizational worlds. When different national interests come into play difficulties in developing cooperation and dialogue are increased. Overcoming major political and cultural divisions is one of the most challenging tasks of the present day. Foregrounded in this is the possibility of cosmopolitan dialogue. Unlike many approaches to inter-cultural dialogue, the idea of a cosmopolitan dialogue suggests a transformation in self-understanding and not merely a better awareness of the perspective of the other. Moreover, it also requires a change in policy making, as opposed to merely a change in consciousness (Nederveen Pieterse, 2006).

Cosmopolitanism is particularly relevant to Europe and Asia. Although generally related to developments pertaining to global civil society and transnational governance beyond the nation-state, it is relevant both to the kinds of normative regionalism that are emerging in Europe and Asia as well as the deeper cultural orientations that are constitutive of their civilizations. Cosmopolitan theory offers a robust approach to current patterns of cooperation between Europe and Asia as well as a normative framework for comparative analysis.

Notes

1. See for example the special issue of the British Journal of Sociology. Vol. 57. No. 1 (2006) on Cosmopolitan Sociology, edited by U. Beck and N. Szaider and the Special issue of the European Journal of Social Theory. Vol. 10. No. 1 (2007) on cosmopolitanism.

2. See for example Breckenridge et al (2002), Cheah and Robbins (1996), Hannerz (1996); Kurasawa (2004), Stribis et al (2001); Stevenson (2002); Vertovec and Cohen (2002). 


\section{The Cosmopolitan Imagination}

Bibliographycal References

ARNASON, Johann P. Civilizations in Dispute: Historical Questions and Theoretical Traditions. Leiden: Brill, 2003.

ARCHIBUGI, Daniele y HELD, David. Cosmopolitan Democracy: An Agenda for a New World Order. Cambridge: Polity Press, 1995.

BECK, Ulrich. The Cosmopolitan Vision. Cambridge: Polity Press, 2006.

BECK, Ulrich y GRANDE, Edgar. Cosmopolitan Europe. Cambridge: Polity Press, 2007.

BECK, Ulrich; SZNAIDER, Nathan y WINTER, Rainer. Global America: The Cultural Consequences of Americanization. Liverpool: Liverpool University Press, 2000.

BOHMAN, James y LUTZ-BACHMANN, Matthias (eds.) Perpetual Peace: Essays on Kant's Cosmopolitan Ideal. Cambridge. MA: MIT Press, 1997.

BRECKENRIDGE, Carol; APPADURAI, Arjun; POLLOCK, Sheldon; BHABHA, Homi y CHARABARTY, Dipesh (eds.) Cosmopolitanism. Durham, NJ: Duke University Press, 2002.

CAMPBELL, Laura B. "The Political Economy of Environmental Regionalism in Asia". In: PEMPEL, T. J. (ed.). Remapping East Asia: The Construction of a Region. Ithaca: Cornell University Press, 2005. P. 216-235.

CHEAH, Pheng y ROBBINS, Bruce (eds.). Cosmopolitics: Thinking and Feeling Beyond the Nation. Minneapolis: Minnesota University Press, 1996.

DALLMAYR, Fred. Beyond Orientalism: Essays on Cross-Cultural Encounter. New York: State University of New York Press, 1996.

DELANTY, Gerard. "The Making of a Post-Western Europe: A Civilizational Analysis". Thesis Eleven. No. 72 (2003). P. 8-24.

- "The Idea of a Cosmopolitan Europe". International Review of Sociology. Vol. 15. No. 3 (2005). P. 405-421.

- "The Cosmopolitan Imagination: Critical Cosmopolitanism and Social Theory", Special Issue on Cosmopolitan Sociology. British Journal of Sociology, 57 (1)(2006a). P. 25-47

- (ed.) Europe and Asia Beyond East and West. London: Routledge, 2006b.

DELANTY, Gerard y RUMFORD, Chris. Rethinking Europe: Social Theory and the Implications of Europeanization. London: Routledge, 2005.

DELANTY, Gerard y KUMAR, Krishan. (eds.) The Sage Handbook of Nations and Nationalism. London: Sage, 2006.

DEUTSCH, Eliot (ed.) Culture and Modernity: East-West Philosophic Perspectives. Honolulu: Hawaii University Press, 1991.

DRYZEK, John S. Deliberative Global Politics: Discourse and Democracy in a Divided World. Cambridge: Polity Press, 2006.

EISENSTADT, S. N. Comparative Civilizations and Multiple Modernities. Vol 1 and 2. Leiden: Brill, 2003.

FRANK, Andre Gunder. Re-Orient: Global Economy in the Asian Age. Berkeley: University of California Press, 1998. 
GAONKAR, Dilip Parameshwar (ed.) Alternative Modernities. Durham, N.C.: Duke University Press, 2001.

HABERMAS, Jürgen. "Toward a Cosmopolitan Europe". Journal of Democracy. Vol. 14. No. 4 (2003). P. 86-100.

HANNERZ, Ulf. Transnational Connections: Culture, People, Places. London: Routledge, 1996 [Trad. Conexiones Transnacionales. Madrid: Cátedra; [ València ] : Universitat de València, 1998].

HE, Baogang. "Cosmopolitan Democracy and the National Identity Question in Europe and East Asia". International Relations of the East-Pacific. No. 2 (2002). P. 47-68.

- "World Citizenship and Transnational Activism". In: PIPER, N. and UHLIN, A. (eds.) Transnational Activism in Asia. London: Routledge, 2004a.

- "Transnational Civil Society and the National Identity Question in East Asia", Global Governance: A Review of Multilateralism and International Organizations. Vol. 10. No. 2 (2004b). P. 227-24.

HERRMANN, Richard K.; RISSE, Thomas y BREWER, Marilynn (eds.) Transnational Identities: Becoming European in the EU. New York: Rowman and Littlefield, 2004.

HUTCHINSON, John. Nations as Zones of Conflict. London: Sage, 2005.

JONES, David Martin. The Image of China in Western Social and Political Thoughts. Hampshire: Palgrave, 2001.

KURASAWA, Fuyuki. "Cosmopolitanism from Below: Alternative Globalization and the Creation of a Solidarity without Bounds”. Arch. Europ. Social. Vol. XLV. No. 2 (2004). P. 233-255.

KYMLICKA, Will y He, Baogang (eds.). Multiculturalism in Asia. Oxford: Oxford University Press, 2005. LAVENEX, Sandra. "EU external governance in 'wider Europe'”. Journal of European Public Policy. Vol. 11. No. 4 (2004). P. 680-700.

LAWSON, Stephanie. Europe and Asia-Pacific: Culture, Identity, and Representations of a Region. London: Routledge Curzon, 2003.

MILWARD, Alan S. The European Rescue of the Nation-State. London: Routledge, 1993.

ONG, Aihwa. Flexible Citizenship: The Cultural Logics of Transnationalism. Durham, NC: Duke University Press, 1999.

NEDERVEEN Pieterse J. "Emancipatory Cosmopolitanism: Towards an Agenda". Development and Change. Vol. 37. No. 6 (2006). P. 1247-1257.

NUSSBAUM, Martha. "Patriotism and Cosmopolitanism". In: COHEN, Joshua. For Love of Country: Debating the Limits of Patriotism. Chicago: University of Chicago Press, 1996.

OOMMEN, T. K. "Socio-Political Transition in the Indian Republic and the European Union". European Journal of Social Theory. Vol. 7. No. 4 (2004). P. 519-37.

POLLACK, S. "Cosmopolitan and Vernacular in History". In: BRECKENRIDGE, Carol A. et al. (Eds.) Cosmopolitanism, Durham, NJ: Duke University Press, 2002.

PRESTON, Peter y GILSON, Julie (eds.) The European Union and East Asia. Heltenham: Edward Elgar, 2001.

RUMFORD, Chris (ed.) Cosmpolitanism and Europe. Liverpool: Liverpool University Press, 2006.

SKRBIS, Zlatko; KENDALL, Gavin y WOODWARD, lan. "Locating Cosmopolitanism: Between Humanist 


\section{The Cosmopolitan Imagination}

Ideas and Grounded Social Category". Theory, Culture and Society. Vol. 21. No. 6 (2001). P.115-36. STEVENSON, Nick. Cultural Citizenship: Cosmopolitan Questions. Buckingham: Open University Press, 2002.

TAN, Kok-Chor. Justice without Borders: Cosmopolitanism, Nationalism and Patriotism. Cambridge: Cambridge University Press, 2004.

THERBORN, Göran. "Post-Western Europe and the Plural Asias". In: DELANTY, Gerard (ed.) Europe and Asia Beyond East and West. London: Routledge, 2006.

TURNER, Beyan S. "Cosmopolitan Virtue: On Religion in a Global Age". European Journal of Social Theory. Vol. 4. No. 2 (2002). P.131-152.

URRY, John. Global Complexity. Cambridge: Polity Press, 2002.

VERTOVEC, Steven y COHEN, Robin (eds). Conceiving Cosmopolitanism, Oxford: Oxford University Press, 2002.

ZIELONKA, Jan. (ed). Europe Unbound: Enlarging and Reshaping the Boundaries of the European Union. London: Routledge, 2002. 